\title{
Hematological and biometric traits of tuvira Gymnotus inaequilabiatus (Valenciennes, 1839) (Gymnotiformes: Gymnotidae) from the Brazilian Pantanal
}

\author{
ROBSON A. RODRIGUES ${ }^{1,2}$, EDUARDA S. SILVA ${ }^{2}$, SANDRIELY F. MARCONDES ${ }^{2}$, GIZELA M. GALINDO ${ }^{2}$, \\ GUSTAVO G. DE OLIVEIRA ${ }^{2}$, ALDA I. DE SOUZA ${ }^{3}$, JOSÉ RAGUSA-NETTO ${ }^{4}$ and CARLOS E. FERNANDES ${ }^{1,2,4}$ \\ ${ }^{1}$ Programa de Pós-Graduação em Ciência Animal, Faculdade de Medicina Veterinária e Zootecnia, Universidade \\ Federal de Mato Grosso do Sul, Av. Senador Filinto Müller, 2443, 79070-900 Campo Grande, MS, Brazil \\ ${ }^{2}$ Laboratório de Patologia Experimental, Instituto de Biociências, Universidade Federal de Mato Grosso \\ do Sul, Av. Costa e Silva, s/n, Bairro Universitário, 79070-900 Campo Grande, MS, Brazil \\ ${ }^{3}$ Programa de Pós-Graduação em Ciências Veterinárias, Faculdade de Medicina Veterinária e Zootecnia, Universidade \\ Federal de Mato Grosso do Sul, Av. Senador Felinto Müller, 2443, 79070-900 Campo Grande, MS, Brazil \\ ${ }^{4}$ Programa de Pós-Graduação em Biologia Animal, Centro de Ciências Biológicas e da Saúde, Universidade Federal \\ de Mato Grosso do Sul, Av. Costa e Silva, s/n, Bairro Universitário, 79070-900 Campo Grande, MS, Brazil
}

Manuscript received on November 16, 2015; accepted for publication on April 15, 2016

\begin{abstract}
This study describes the hematological and biometric characteristics of male and female Gymnotus species from the Pantanal, Mato Grosso do Sul state, Brazil. Fifty adult specimens of Gymnotus inaequilabiatus were weighed, measured, and then euthanized. Blood was collected by puncturing the celiac mesenteric vein to determine the hematocrit, hemoglobin content, number of erythrocytes, mean corpuscular volume, mean corpuscular hemoglobin concentration, glucose level, absolute value of leukocytes, and relative value of leukocytes and thrombocytes. Body weight and relative condition factor did not differ $(\mathrm{P}>0.05)$ between the sexes, as well as erythrogram and the blood glucose values. Hematocrit ranged from $18.0 \%$

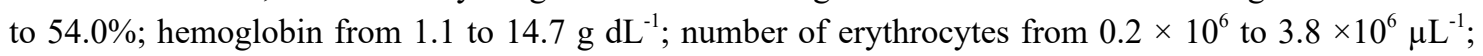
MCV from 24.2 to $321.7 \mathrm{fL}$; and MCHC from 4.2 to $44.5 \mathrm{~g} \mathrm{dL}^{-1}$. In the differential count were identified thrombocytes, lymphocytes, neutrophils, monocytes, basophils, immature leukocytes, and PAS-positive granular leukocyte (PAS-GL). Females had a higher percentage of immature leukocytes $(\mathrm{P}<0.05)$ than males. Glucose levels, erythrogram, leukogram, and the morphology of defense cells are comparable to other fish species of the Pantanal. Thrombocytes were the most frequent defense cells, followed by lymphocytes and neutrophils.
\end{abstract}

Key words: blood glucose, erythrogram, leukocytes, sex differences, thrombocytes.

\section{INTRODUCTION}

The Gymnotiformes, commonly known as knifefishes, are a small endemic group that constitute

Correspondence to: Robson Andrade Rodrigues

E-mail: robson.andrade.rodrigues17@hotmail.com approximately $3 \%$ of the Neotropical ichthyofauna (Reis et al. 2003). The family Gymnotidae has the widest geographical distribution within the order, ranging from central Argentina to the Mexican southeast (Albert 2001). 
The genus Gymnotus is popularly referred to as "tuvira" or "sarapó," and is an important economic resource in the Pantanal region. These fish are caught in the natural environment and used as live bait by tourists and professional fishers. There is thus commercial link involving the exploitation of this species, and substantial efforts have been made to grow them on fish farms (Rotta et al. 2007, Resende et al. 2006). In general, Gymnotus spp. are active at night in aquatic macrophyte environments populated by salvinia Salvinia auriculata, creeping bladderwort Utricularia gibba, South American spongeplant Limnobium laevigatum, and mosaic flower Ludwigia sedoides. The roots of these plants provide a suitable environment for the fish to feed on insects, their preferred food (Resende et al. 2006).

Due the diversity of the Pantanal ichthyofauna, data on the hematological parameters of wild Pantanal fish are poor; include a basic description and its relation with biotic and abiotic factors (Seriani and Ranzani-Paiva 2012). Therefore, the maintenance of native species will depend upon research that will provide us with a better understanding of biological cycles and their interactions in the environment. In the Pantanal region, these fish experience periodic flooding conditions and may have developed adaptive physiological strategies to survive, especially during the drier aestivation periods. During these periods, many fish species are confined to temporary ponds and are subjected to adverse conditions such as large temperature fluctuations, food scarcity, and parasitism (Britski et al. 1999, Barton et al. 2002, Rios et al. 2005).

Hematology has been used as a tool to study the physiology and health of various fish species, especially in the natural environment (RanzaniPaiva et al. 2000). Furthermore, the analysis and interpretation of different hematological parameters provides relevant information for the prognosis and diagnosis of many disorders, and helps us to understand the process of physiological adaptation in captivity (Tavares-Dias and Moraes 2004). Additionally, hematological parameters vary depending upon species, age, sexual maturity, health status, and the aquatic biotope (Radu et al. 2009). It is well known that blood comprises $1.3 \%-7.0 \%$ of the total body weight in fish, and it represents, in association with the hematopoietic organs, a critical biomarker for metabolic processes and physiological stress in response to changes in exogenous and endogenous conditions (Morgan and Iwama 1997). The correct evaluation of hematological parameters thus depends upon the availability of reference values. These should be as close as possible to the normal values of various blood components as found in healthy fish under natural conditions (Tavares-Dias and Moraes 2004).

The aim of this study was to establish basal hematological and biometric values for tuvira Gymnotus inaequilabiatus (Valenciennes 1839) in the Pantanal of Mato Grosso do Sul State, Brazil. Additionally, we investigated the effects of environmental conditions on a set of variables that could be used as reference standards in future studies of this species.

\section{MATERIALS AND METHODS}

Adult specimens of tuvira $G$. inaequilabiatus (26 males and 25 females) from Porto Morrinho, Mato Grosso do Sul $\left(21^{\circ} 41^{\prime} 56^{\prime \prime} \mathrm{S}, 57^{\circ} 52^{\prime} 57^{\prime \prime} \mathrm{W}\right)$, were acquired between September 2013 and November 2014 from a specialized live bait supplier in Campo Grande, MS. The fish were transported to the laboratory in oxygenated polyethylene bags, and then were kept at a constant temperature $\left(25.0^{\circ} \mathrm{C}\right)$ for $2 \mathrm{~h}$ in aquariums supplied with artificial aeration until euthanasia (2-phenoxyethanol, $\left.2 \mathrm{~mL} \mathrm{~L}^{-1}\right)$. Following euthanasia, the fish were weighed (total weight in grams) and measured (total length in centimeters). These variables were 
used to estimate the relative condition factor $(K n)$ according the equation $K n=W / a L^{b}$, where $W$ is weight of the individual, $L$ is the standard length of the individual, and $a$ and $b$ are the constants from the weight-length relation (Le Cren 1951).

Blood was collected through the celiac mesenteric vein with a syringe and disposable EDTA needles, immediately after opening the abdominal cavity. The hematological parameters measured were hematocrit (\%) according (Goldenfarb et al. 1971), hemoglobin content $\left(\mathrm{g} \mathrm{dL}^{-1}\right)$ according (Collier 1944), and erythrocyte count $\left(\times 10^{6} \mu \mathrm{L}^{-1}\right)$ using a Neubauer chamber. Mean corpuscular volume (fL) and mean corpuscular hemoglobin concentration $\left(\mathrm{g} \mathrm{dL}^{-1}\right)$ were calculated from the results obtained for number of erythrocytes, hematocrit, and hemoglobin content following Wintrobe (1934). Cells differential counts (leukocytes and thrombocytes) in blood extensions were stained by the May-Grünwald-Giemsa method using 200 cells per sample (Tavares-Dias et al. 2002). The total count of leukocytes was performed by hemocytometer technique (RanzaniPaiva et al. 2013). The glucose level ( $\mathrm{mg} \mathrm{dL}^{-1}$ ) was measured by an in vitro test with a drop of a total blood (Accu-Chek Active; Roche Diagnostics).

The procedures adopted in this study are in accordance with Resolution No. 714 of June 2012, CFMV, certified by the Ethics Committee on Animal Use (CEUA\UFMS protocol 557/2013).
Descriptive statistics calculated included the mean, standard error of the mean, minimum and maximum values, and confidence interval of the mean (CI 95\%). The effect of sex was tested by the Mann-Whitney $U$ test (Z, asymptotic significance, 2-tailed). An exploratory factor (dimension reduction) with varimax rotation and principal component analysis (PCA) was also used to assess the data set of biometric and hematological variables. The initial selection of variables was based on commonalities values $\geq$ 0.60 , using a Kaiser-Meyer-Olkin (KMO) measure of sampling adequacy of 0.80 or more and Bartlett's test of sphericity $(\mathrm{P}<0.001)$. After selection, a new PCA model adjusted to two factors with normalized correlation was prepared. PCA scores were computed using vector products with the standardized data. SPSS 17.0 (IBM $\left.{ }^{\circledR}\right)$ and PAST 2.17 (Hammer et al. 2001) software were used in the analysis.

\section{RESULTS}

G. inaequilabiatus specimens had a mean weight of $137.0 \pm 26.2 \mathrm{~g}$, a mean length of $34.1 \pm 2.2 \mathrm{~cm}$, and their condition factor was $1.0 \pm 0.02$. There was no difference $(\mathrm{P}>0.05)$ between the sexes in biometric measurements (Table I). Similarly, the erythrogram and glucose levels did not differ (Table II). Immature leukocytes were more abundant in females than in males, but no other cell categories

TABLE I

Means, standard error of the means (SEM), minimum (Min) and maximum (Max) values and confidence intervals (CI $\mathbf{9 5 \% )}$ of biometric variables of male and female tuvira Gymnotus inaequilabiatus from Brazilian Pantanal.

\begin{tabular}{cccccc}
\hline Variables & Sex & Mean \pm SEM & Min-Max & CI (95\%) & P \\
\hline \multirow{2}{*}{ Weight $(\mathrm{g})$} & Male & $137.13 \pm 6.00$ & $101.90-218.60$ & $124.51-149.72$ & 0.47 \\
\hline \multirow{2}{*}{ Length $(\mathrm{cm})$} & Female & $132.02 \pm 5.34$ & $94.60-190.40$ & $120.80-143.22$ & $33.81-36.03$ \\
& Male & $34.93 \pm 0.52$ & $29.50-38.50$ & $32.55-34.72$ & 0.12 \\
\hline \multirow{2}{*}{ Kn } & Female & $33.63 \pm 0.51$ & $28.5-38.00$ & $0.99-1.03$ & $0.99-1.05$ \\
\end{tabular}

Kn: Relative condition fator; P: Mann-Whitney U test. 
showed any sex differences $(\mathrm{P}>0.05)$. Eosinophils presented less than $1.0 \%$ and were not considered in the analysis (Table III).

Figure 1 shows the PCA results. Hematocrit, hemoglobin, MCHV, glucose level, total leukocytes, neutrophils, lymphocytes and PASpositive granular leukocyte (PAS-GL) were selected from the total of the variables analyzed. Lymphocytes were separated into alone grouping to the neutrophils, PAS-GL and glucose levels. Total leukocytes, MCHV, hemoglobin, and hematocrit maintained a homogeneous group. This result suggested that the innate immunity apparatus could be more explored in this species of fish.

\section{DISCUSSION}

The tuvira $G$. inaequilabiatus is a typical species of the lentic environments characteristic of the Pantanal. It is adapted to low oxygen environments and usually lives in small ponds and exhibits little migration (Almeida-Val et al. 1993). There is no sexual dimorphism; sex was determined by necropsy when the specimens were opened for blood collection. This method made it possible to quickly obtain samples suitable for laboratory procedures.

The weight-length ratio did not differ between males and females. In fish, this ratio reflects information about the physiological state of the specimen in relation to its health and describes structural characteristics of individuals within populations (Anderson and Gutreuter 1983). In other wild fish species this ratio is higher in females during the reproductive/spawning season due to added ovarian weight (Tavares-Dias et al. 2004). Whereas the female Gymnotus spp. have multiple spawning (Rotta et al. 2007), possibly the number obtained in this study $(\mathrm{n}=25)$ was not enough to reveal significant difference between the sexes. The observed values are in agreement with other species and suggest homogeneity in the study population.

Wild fish from natural environments may exhibit different physiological behaviors related to their survival strategies. The hematological parameters of these species may vary in response to age, sex, water quality, season, stress, infection conditions, capture method, handling, and anesthetic agents (Moraes et al. 2002, Ranzani-

TABLE II

Means, standard error of the means (SEM), minimum and maximum values and confidence interval (CI 95\%) of erythrocytic parameters and blood of male and female tuvira Gymnotus inaequilabiatus from Brazilian Pantanal.

\begin{tabular}{|c|c|c|c|c|c|}
\hline Variables & Sex & Mean \pm SEM & Min-Max & CI $(95 \%)$ & $\mathrm{P}$ \\
\hline \multirow{2}{*}{ Htc $(\%)$} & Male & $35.63 \pm 1.80$ & $22.00-54.00$ & $31.84-39.42$ & \\
\hline & Female & $37.50 \pm 1.47$ & $18.00-48.00$ & $34.43-40.57$ & 0.73 \\
\hline \multirow{2}{*}{$\mathrm{Hb}\left(\mathrm{g} \mathrm{dL}^{-1}\right)$} & Male & $8.64 \pm 0.71$ & $1.10-14.70$ & $7.15-10.14$ & \\
\hline & Female & $9.86 \pm 0.42$ & $5.5-13.8$ & $8.98-10.74$ & 0.17 \\
\hline \multirow{2}{*}{$\operatorname{Er}\left(\mathrm{x} 10^{6} \mu \mathrm{L}^{-1}\right)$} & Male & $1.99 \pm 0.15$ & $0.87-3.19$ & $1.66-2.32$ & \\
\hline & Female & $2.06 \pm 0.14$ & $1.15-3.58$ & $1.75-2.37$ & 0.43 \\
\hline \multirow{2}{*}{ MCV (fL) } & Male & $195.80 \pm 17.04$ & $113.70-448.30$ & $159.99-231.61$ & \\
\hline & Female & $194.72 \pm 12.56$ & $120.10-321.70$ & $168.43-221.02$ & 0.88 \\
\hline \multirow{2}{*}{$\operatorname{MCHV}\left(\mathrm{g} \mathrm{dL}^{-1}\right)$} & Male & $23.85 \pm 1.15$ & $4.20-34.60$ & $20.81-26.90$ & \\
\hline & Female & $26.62 \pm 1.45$ & $21.00-44.50$ & $24.22-29.02$ & 0.17 \\
\hline \multirow{2}{*}{ Glucose $\left(\mathrm{mg} \mathrm{dL}^{-1}\right)$} & Male & $100.90 \pm 6.90$ & $58.00-173.00$ & $85.60-116.19$ & \\
\hline & Female & $97.15 \pm 7.28$ & $43.00-151.00$ & $82.70-111.60$ & 0.69 \\
\hline
\end{tabular}

$\mathrm{Htc}=$ Hematocrit; $\mathrm{Hb}=$ Hemoglobin; Er= Erythrocytes; $\mathrm{MCV}=$ mean corpuscular volume; $\mathrm{MCHV}=$ mean corpuscular hemoglobin volume; P: Mann-Whitney U test. 
TABLE III

Means, standard error of the means (SEM), minimum (Min) and maximum (Max) values and confidence intervals (CI $\mathbf{9 5 \% )}$ of leukocytes and thrombocytes and total leukocytes of male and female tuvira Gymnotus inaequilabiatus from Brazilian Pantanal.

\begin{tabular}{|c|c|c|c|c|c|}
\hline & Sex & Mean \pm SEM & Min-Max & CI $(95 \%)$ & $\mathrm{P}$ \\
\hline \multirow{2}{*}{ Lymphocytes (\%) } & Male & $28.24 \pm 3.48$ & $8.00-58.00$ & $20.93-35.54$ & \\
\hline & Female & $22.48 \pm 2.65$ & $10.50-57.00$ & $16.92-28.03$ & 0.21 \\
\hline \multirow{2}{*}{ Neutrophil (\%) } & Male & $18.45 \pm 2.13$ & $7.50-37.00$ & $13.97-22.92$ & \\
\hline & Female & $22.33 \pm 2.36$ & $6.50-44.5$ & $17.38-27.27$ & 0.88 \\
\hline \multirow{2}{*}{ Monocytes (\%) } & Male & $5.97 \pm 0.90$ & $1.00-19.50$ & $4.09-7.86$ & \\
\hline & Female & $6.50 \pm 0.90$ & $0.50-14.00$ & $4.62-8.38$ & 0.63 \\
\hline \multirow{2}{*}{ Thrombocytes (\%) } & Male & $42.18 \pm 2.46$ & $19.50-60.00$ & $37.03-47.34$ & \\
\hline & Female & $41.00 \pm 3.26$ & $12.50-66.00$ & $34.18-47.82$ & 0.97 \\
\hline \multirow{2}{*}{ Basophils (\%) } & Male & $1.70 \pm 0.44$ & $0.00-6.50$ & $0.85-2.72$ & \\
\hline & Female & $3.20 \pm 0.94$ & $0.00-19.00$ & $1.23-5.18$ & 0.09 \\
\hline \multirow{2}{*}{ Immature leukocytes (\%) } & Male & $2.84 \pm 0.41$ & $0.50-7.00$ & $1.98-3.71$ & \\
\hline & Female & $3.70 \pm 0.42$ & $1.50-9.00$ & $2.82-4.58$ & 0.05 \\
\hline \multirow{2}{*}{ PAS-GL } & Male & $0.53 \pm 0.16$ & $0.00-2.00$ & $0.19-0.86$ & \\
\hline & Female & $0.78 \pm 0.30$ & $0.00-6.00$ & $0.15-1.40$ & 0.25 \\
\hline \multirow{2}{*}{ Total leukocytes $\left(\times 10^{3} \mu \mathrm{L}^{-1}\right)$} & Male & $6.89 \pm 0.47$ & $3.08-10.34$ & $5.90-7.89$ & \\
\hline & Female & $7.50 \pm 0.10$ & $3.30-23.98$ & $5.40-9.60$ & 0.63 \\
\hline
\end{tabular}

PAS-GL: PAS-positive granular leukocyte; P: Mann-Whitney U test.

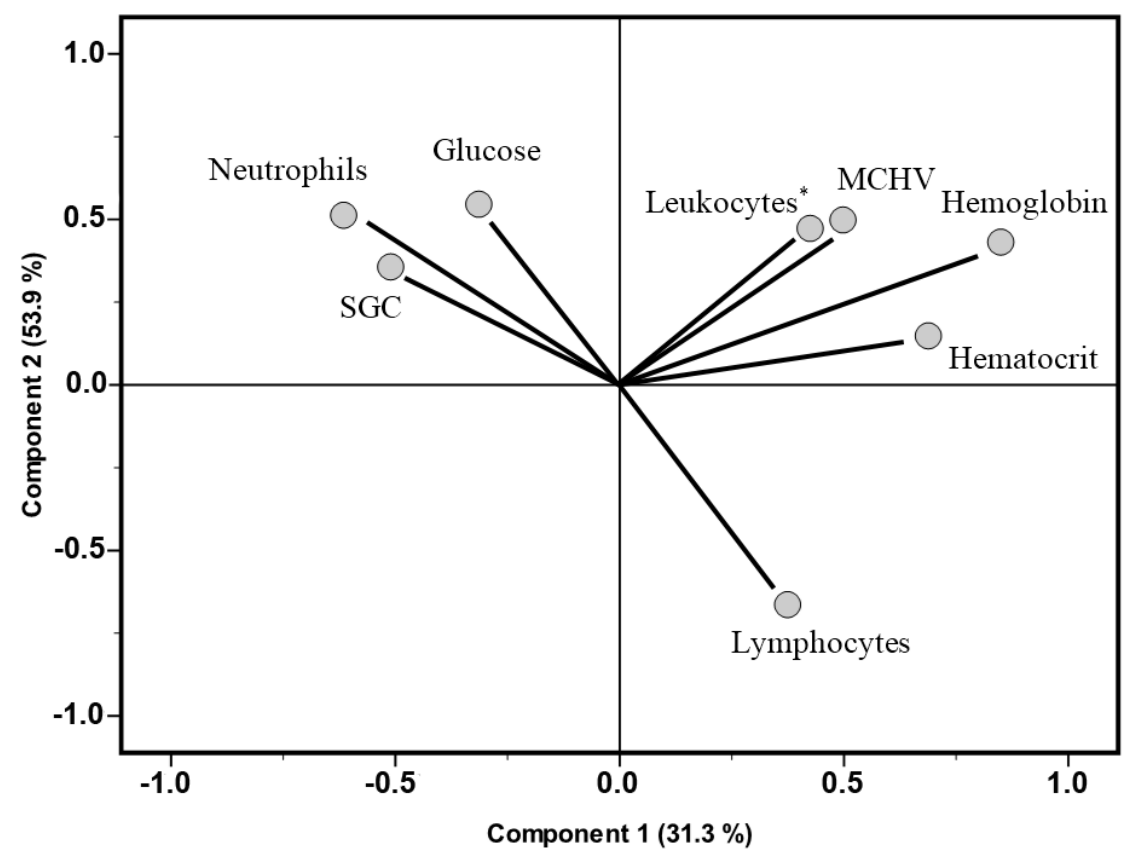

Figure 1 - Principal component biplot of starling hematological data of tuvira Gymnotus inaequilabiatus from Brazilian Pantanal, Brazil. MCHV: mean corpuscular hemoglobin concentration; PAS-GL: PAS-positive granular leukocyte; " total count. 
Paiva et al. 2005, Drumond et al. 2010, RioZaragoza et al. 2010). Therefore, data evaluation becomes a challenge due the lack of meaningful reference standards. Erythrogram averages found in tuvira $G$. inaequilabiatus were higher than those described in other fish such as jundiá Rhamdia quelen (Tavares-Dias et al. 2002). The hematocrit was similar to piauçu Leporinus macrocephalus and curimbatá Prochilodus lineatus, however the count of erythrocytes and the concentration of hemoglobin were higher, while the mean corpuscular volume and mean corpuscular hemoglobin concentration were lower (Tavares-Dias et al. 2008a). This profile may have relevance to the hematocrit investigation. Fish adapted to lower oxygen levels usually present higher values for erythrocytes and hemoglobin. The facultative air-breathing abilities of Gymnotus spp., which have swim bladders that are quite vascularized, are probably involved in this adaptive process, particularly during the dry season (Rotta 2004, Mariano et al. 2011).

The glucose data were comparable to previous studies in other species such as tambaqui Colossoma macropomum and pirarucu Arapaima gigas according to Tavares-Dias and Sandrim (1998) and Tavares-Dias et al. (2007). However, these values were higher in comparison to species reared in captivity such as pacu Piaractus mesopotamicus, matrinxã Brycon cephalus and piraputanga Brycon orbignyanus (Tavares-Dias and Mataqueiro 2004, M. Tavares-Dias, unpublished data, Tavares-Dias and Moraes 2006). Blood glucose level is a suitable biomarker to evaluate the level of stress in many fish species living in tropical environments. The natural environment of tuvira Gymnotus spp. is characterized by low levels of oxygen and limited water movement (Rotta 2004, Resende et al. 2006). Therefore, the ranges found in the present study suggest a physiological adjustment in response to that condition. Increased levels of glucose in the liver and kidney were observed after hypoxia exposure in tuvira G. carapo (Moraes et al. 2002).
The morphology of leukocytes and thrombocytes has been studied in the Characiformes (tambaqui Colossoma macropomum, traíra Hoplias malabaricus, dourado Salminus maxillosus, dourado Salminus brasiliensis, lambari Astyanax bimaculatus), Cypriniformes (carpa Cyprinus carpio), Perciformes (oscar Astronotus ocellatus), and Siluriformes (abotoado Oxydoras niger, jundiá Rhamdia quelen) (Tavares-Dias et al. 1999, 2002, Ranzani-Paiva et al. 2003, TavaresDias 2006, Pádua et al. 2009, Santos and TavaresDias 2010). Subtle variations in cell morphology were observed, although leukocyte classification was still possible. The normal of leukocytes morphology features is an important premise for identification of the changes in the leukogram. In fish, attention should be given to the PAS-GL. This cell is a granulocyte, relatively larger than the neutrophils, with small eccentric nuclei with dense chromatin. The cytoplasm have abundant granules, which are PAS positive. In some species, the presence of white cytoplasmics granules can give the false impression of morphological changes (Ranzani-Paiva et al. 2013). In other studies the PAS-GL was described in 30 teleosts both freshwater and saltwater (Barber and Westermann 1978). In brazilian teleosts, this cell is commonly described in the peripheral blood (Tavares-Dias et al. 2004, Tavares-Dias 2006, Ranzani-Paiva et al. 2013), mainly in fish affected by parasites (TavaresDias and Moraes 2004, Ranzani-Paiva et al. 2013, Campos et al. 2014). However, the percentages of some leukocytic forms were more variable than in others studies (Tavares-Dias et al. 2002, RanzaniPaiva et al. 1999, Pádua et al. 2012, Figueiredo et al. 2014). These differences are difficult to explain due to the variability of biotic and abiotic factors associated with these fish communities. On the other hand, macrophages and granulocytes lack specificity and this allows large numbers of cells to be mobilized quickly to interact with the cells of the specific immune system. Moreover, these cells 
can confound the interpretation of results when attempting to make conclusions about the degree of stress present in parasitized fish (Tavares-Dias et al. 2008b).

Usually, the leukocyte percentage is described by mean and standard deviation without considering the relationships among the variables. These relationships may be useful in interpreting the defense response, although many of them do not relate to each other. PCA is a multidimensional tool used to reduce a set of original variables and to extract a small number of latent factors. Furthermore, it helps identify relations among subpopulations with similar profiles (Sparks 2000). In the present study, the lymphocytes split themselves from the neutrophils, PAS-GL and glucose. This arrangement in the opposite side of the graphic (Fig. 1) suggests that many individual fish had high lymphocyte percentages at the moment of the blood collection in comparison to others. This reflects typical variation due to stressful situations, considering the patterns of neutrophils, lymphocytes, and glucose levels (Barton 2002, Adeyemo et al. 2009). The magnitude of the stress response to capture, transport, handling and anesthesia varies substantially among species, and, typically, the effects are apparent for several days after the stress event (Harper and Wolf 2009).

Taking into account the limited information on tuvira G. inaequilabiatus in Brazil, and especially in the Pantanal region, these hematological parameters may be used as preliminary reference values. However, further studies are required on other variables related to environmental or biotic factors in the context of commercial rearing. In conclusion, glucose levels, erythrogram, and leukogram results of tuvira $G$. inaequilabiatus correspond to those of other species of the Pantanal, including the morphology of the leukocytes. Furthermore, thrombocytes were the most frequent defense cells in the peripheral blood, followed by lymphocytes and neutrophils.

\section{REFERENCES}

ADEYEMO OK, NAIGAGA I AND ALLI RA. 2009. Effect of handling and transportation on haematology of african catfish (Clarias gariepinus). J Fish Sci 3: 333-341.

ALBERT JS. 2001. Species diversity and phylogenetic systematics of American knifefishes (Gymnotiformes, Teleostei). Misc Publ 190: 1-127.

ALMEIDA-VAL VMF, VAL AL AND HOCHACHKA PW. 1993. Hypoxia tolerance in Amazon fishes: status of an under-explored biological "goldmine". In: Hochachka PW, Lutz PL, Sick T, Rosenthal M and Van Der Thilllart G (Eds), Surviving hypoxia: mechanism of control and adaptation. Boca Raton: CRC Press, Boca Raton, USA, p. 436-445.

ANDERSON RO AND GUTREUTER SJ. 1983. Length, weight, and associated structural indices. In: Nielsen L and Johnson D (Eds), Fisheries Techniques. Bethesda: American Fisheries Society, Bethesda, USA, p. 284-300.

BARBER DL AND WESTERMANN JEM. 1978. Occurrence of the periodic acid Schiff positive granular leucocyte (PAS-GL) in some fishes and its significance. J Fish Biol 12: 35-43.

BARTON BA. 2002. Stress in Fishes: A diversity of responses with particular reference to changes in circulating corticosteroids. Integr Comp Biol 42: 517-525.

BARTON BA, MORGAN JD AND VINAYAN MM. 2002. Physiological and condition-related indicators of environmental stress in fish. In: Adams M (Ed), Biological indicator of aquatic ecosystem stress. Bethesda: American Fisheries Society. Bethesda, USA, p. 289-320.

BRITSKI HA, SILIMON KZS AND LOPES BL. 1999. Peixes do Pantanal: manual de identificação. Brasília, Embrapa, $227 \mathrm{p}$.

CAMPOS CM, RODRIGUES RA, OLIVEIRA CAL, NUNES AL, FANTINI LE AND USHIZIMA TT. 2014. Permanganato de potássio como agente terapêutico no controle de Epistylis sp. em cachara Pseudoplatystoma reticulatum e seus efeitos na hematologia. Inst Bol Pesca 40: $157-166$.

COLLIER HB. 1944. The standardizations of blood haemoglobin determinations. CMAJ 50: 550-552.

DRUMOND GVF, CAIXEIRO APA, TAVARES-DIAS M, MARCON JL AND AFFONSO EG. 2010. Características bioquímicas e hematológicas do pirarucu Arapaima gigas Schinz, 1822 (Arapaimidae) de cultivo semi-intensivo na Amazônia. Acta Amaz 40: 591-596.

FIGUEIREDO AB, TANCREDO KR, HASHIMOTO GSO, ROUMBEDAKIS K, MARCHIORI NC AND MARTINS ML. 2014. Haematological and parasitological assessment of silver catfish Rhamdia quelen farmed in Southern Brazil. Rev Bras Parasitol Vet 23: 157-163. 
GOLDENFARB PB, BOWYER FP, HALL E AND BROSIOUS E. 1971. Reproducibility in the hematology laboratory: the microhematocrit determinations. Am J Clin Pathol 56: 35-39.

HAMMER Ø, HARPER DAT AND RYAN PD. 2001. PAST: Paleontological statistics software package for education and data analysis. Palaeontol Electron 4: 1-9.

HARPER C AND WOLF JC. 2009. Morphologic Effects of the Stress Response in Fish. ILAR 50: 387-396.

LE CREN ED. 1951. The Length-Weight Relationship and Seasonal Cycle in Gonad Weight and Condition in the Perch (Perca fluviatilis). J Anim Ecol 20: 201-219.

MARIANO WS, SORIA SFP, GARCIA RG, FÉLIX-ZÁRATE M, LOPES F AND TOLEDO JRS. 2011. Metabolismo e fisiologia de tuvira, Gymnotus carapo (Linnaeus, 1758) submetidos à exposição ao ar atmosférico. Ens Cienc 15: 9-18.

MORAES G, AVILEZ IM, ALTRAN AE AND BARBOSA CC. 2002. Biochemical and hematological responses of the banded knife fish Gymnotus carapo (Linnaeus, 1758) exposed to environmental hypoxia. Braz J Biol 62: 633640.

MORGAN JD AND IWAMA GK. 1997. Measurements of stressed states in the field. In: Iwama GK, Pickering AD, Sumper JD and Schreck CB (Eds), Fish Stress and Health in Aquaculture. Cambridge Univ. Press, Cambridge, UK, p. 247-278.

PÁDUA SB, ISHIKAWA MM, SATAKE F, HISANO H AND TAVARES-DIAS M. 2009. Leucogram and thrombogram values of juveniles dourado (Salminus brasiliensis) in experimental condition of culture. Rev Bras Med Vet 31: 282-287.

PÁDUA SB, VENTURA AS, SATAKE F, ISHIKAWA MM, HISANO H, ROTTA MA AND ARANTE FC. 2012. Respostas hematológicas em tuviras após anestesia com diferentes concentrações de óleo de cravo. Bol Inst de Pesca 38: 181-188.

RADU D, OPREA L, BUCUR C, COSTACHE M AND OPREA D. 2009. Characteristics of haematological parameters for carp culture and Koi (Cyprinus carpio Linneaus, 1758) reared in an intensive system. J Anim Sci Biotechnol 66: 1-2.

RANZANI-PAIVA MJT, PÁDUA SB, TAVARES-DIAS M AND EGAMI MI. 2013. Métodos para análise hematológica em peixes. Maringá, EDUEM, 140 p.

RANZANI-PAIVA MJT, RODRIGUES EL, VEIGA ML, EIRAS AC AND CAMPOS BES. 2003. Differential leukocyte counts in "Dourado" Salminus maxillosus Valenciennes, 1840, from the Mogi-Guaçu river, Pirassununga, SP. Braz J Biol 63: 517-525.

RANZANI-PAIVA MJT, ROMAGOSA E AND ISHIKAWA CM. 2005. Hematological parameters of "Cachara", Pseudoplatystoma fasciatum Linnaeus, 1766
(Osteichthyes, Pimelodidae), reared in captivity. Bol Inst Pesca 31: 47-53.

RANZANI-PAIVA MJT, SALLES FA, EIRAS JC, EIRAS AC, ISHIKAWA CM AND ALEXANDRINO AC. 1999. Análises hematológicas de curimbatá (Prochilodus scrofa), pacu (Piaractus mesopotamicus) e tambaqui (Colossoma macropomum) das estações de piscicultura do Instituto de Pesca, Estado de São Paulo. Bol Inst Pesca 25: 77-83.

RANZANI-PAIVA MJT, SOUZA ATS, PAVANELLI GC, TAKEMOTO RM AND EIRAS AC. 2000. Hematological evaluation in commercial fish species from the floodplain of upper Paraná River, Brazil. Acta Sci 22: 507-513.

REIS RE, KULLANDER SO AND FERRARIS JUNIOR CJ. 2003. Check list of the freshwater fishes of South and Central America. Porto Alegre: Edipucrs, 729 p.

RESENDE EK, PEREIRA RAC, SÓRIO VF AND GALVÃO EM. 2006. Biologia da tuvira, Gymnotus cf. carapo (Pisces, Gymnotidae) no Baixo Rio Negro, Pantanal, Mato Grosso do Sul, Brasil. Corumbá: Embrapa Pantanal, 42 p.

RIOS FS, OBA ET, FERNANDES MN, KALININ AL AND RANTIN RT. 2005. Erythrocyte senescence and haematological changes induced by starvation in the neotropical fish traíra, Hoplias malabaricus (Characiformes, Erythrinidae). Comp Biochem Phys A 140: 281-287.

RIO-ZARAGOZA OB, FAJER-AVILA EJ AND RUEDAALMAZÁN P. 2010. Haematological and gill responses to an experimental infection of dactylogyrid monogeneans on the spotted rose snapper Lutjanus guttatus (Steindachner, 1869). Aquac Res 41: 1592-1601.

ROTTA MA. 2004. Aspectos Biológicos e Reprodutivos para a Criação da Tuvira (Gymnotus sp.) em Cativeiro - I. Corumbá: Embrapa Pantanal, 30 p.

ROTTA MA, PEDROSO MF AND ACORCI LC. 2007. Determinação do Sexo da Tuvira Gymnotus sp. Através da Análise de Imagem de Ultra-Som. Corumbá: Embrapa Pantanal, $16 \mathrm{p}$.

SANTOS RBS AND TAVARES-DIAS M. 2010. Células sanguíneas e resposta hematológica de Oxydoras niger (Pisces: Doradidae) oriundos da bacia do médio Rio Solimões, Estado do Amazonas (Brasil), naturalmente parasitados. Bol Inst Pesca 36: 283-292.

SERIANI R AND RANZANI-PAIVA MJ. 2012. Alterações hematológicas em peixes: Aspectos fisiopatológicos e aplicações em ecotoxicologia aquática. In: Silva-Souza AT, Lizama MAP and Takemoto RM (Eds), Patologia e Sanidade de Organismos Aquáticos. Maringá: ABRAPOA, p. $221-242$

SPARKS T. 2000. Statistical in Ecotoxicology. New York: J Wiley \& Sons Ltda, 320 p.

TAVARES-DIAS M. 2006. A morphological and cytochemical study of erythrocytes, thrombocytes and leukocytes in four freshwater teleosts. J Fish Biol 68: 1822-1833. 
TAVARES-DIAS M, BARCELLOS JFM, MARCON JL, MENEZES GC, ONO EA AND AFFONSO EG. 2007. Hematological and biochemical parameters for the pirarucu Arapaima gigas (Schinz, 1822) (Osteoglossiformes: Arapaimatidae) in net cage culture. Electron J Ichthyol 2: 61-68.

TAVARES-DIAS M, BOZZO FR, SANDRIN EFS, CAMPOSFILHO E AND MORAES FR. 2004. Células sangüíneas, eletrólitos séricos, relação hepato e esplenossomática de carpa-comum, Cyprinus carpio (Cyprinidae) na primeira maturação gonadal. Acta Sci 26: 73-80.

TAVARES-DIAS M AND MATAQUEIRO MI. 2004. Características hematológicas, bioquímicas e biométricas de Piaractus mesopotamicus Holmberg, 1887 (Osteichthyes: Characidae) oriundos de cultivo intensivo. Acta Sci Biol 26: 157-162.

TAVARES-DIAS M, MELO JFB, MORAES G AND MORAES FR. 2002. Características hematológicas de teleósteos brasileiros. IV. variáveis do jundiá Rhamdia quelen (Pimelodidae). Cienc Rural 32: 693-698.

TAVARES-DIAS M AND MORAES FR. 2004. Hematologia de Peixes Teleósteos. Ribeirão Preto: Marcos Tavares Dias, $144 \mathrm{p}$.

TAVARES-DIAS M AND MORAES FR. 2006. Hematological parameters for the Brycon orbignyanus (Valenciennes,
1850) (Osteichthyes: Characidae) intensively bred. Hidrobiológica 16: 271-274.

TAVARES-DIAS M, MORAES FR AND IMOTO ME. 2008a. Hematological parameters in two neotropical freshwater teleost, Leporinus macrocephalus (Anostomidae) and Prochilodus lineatus (Prochilodontidae). Biosc J 24: 96101.

TAVARES-DIAS M, MORAES FR AND MARTINS ML. 2008b. Hematological assessment in four brazilian teleost fish with parasitic infections, collected in feefishing from Franca, São Paulo, Brazil. Bol Inst Pesca 34: 189-196.

TAVARES-DIAS M AND SANDRIM EFS. 1998. Características hematológicas de teleósteos brasileiros. I. Série vermelha e dosagens de cortisol e glicose do plasma sangüíneo de espécimes de Colossoma macropomum em condições de cultivo. Acta Sci 20: 157-160.

TAVARES-DIAS M, SANDRIM EFS AND CAMPOSFILHO E. 1999. Características hematológicas do tambaqui Colossoma macropomum Cuvier (Osteichthyes, Characidae) em sistema de monocultivo intensivo. II. Leucócitos. Rev Bras Zoo 16: 175-184.

WINTROBE MM. 1934. Variations in the size and hemoglobin content of erythrocytes in the blood of various vertebrates. Folia Haematol 51: 32-49. 